\title{
Development of Transactional Analysis Techniques Group Counseling Guidebook to Improve Students' Self Esteem
}

\author{
Ni Ketut Sinta Kurnia Sari ${ }^{\left.1^{*}\right)}$, I Ketut Gading ${ }^{2}$, I Ketut Dharsana ${ }^{3}$ \\ 1,2,3 Universitas Pendidikan Ganesha \\ *Corresponding author, e-mail: sintakurniasari22@gmail.com
}

Received August 02, 2021; Revised August 31, 2021; Accepted Sept. 20, 2021; Published Online 2021-10-01

\section{Conflict of Interest} Disclosures:

The authors declare that they have no significant competing financial, professional or personal interests that might have influenced the performance or presentation of the work described in this manuscript.

\begin{abstract}
This research has purposes to test the feasibility of a transactional analysis technique group counseling guidebook to improve the self-esteem of vocational students. This research is a $4 \mathrm{D}$ development research model. The guidebook product acceptance tester involved 5 experts and guidance and counseling practitioners. Testing the validity of the content of the manual product using the Lawshe formula. The result of the research based on content validity analysis is that the CVR value per item is greater than $0(\mathrm{CVR}>0)$ and there is no item with a value less than $0(C V R<0)$. Furthermore, the results of the Lawshe CVI analysis obtained a score of 1, it can be interpreted that the acceptance of this guidebook is very high. So based on the value of the acquisition of effectiveness above, according to the criteria, showing an effect size value $>0.50$, the transactional analysis technique group counseling guide can be accepted.
\end{abstract}

Keywords: Handbook, Group Counseling, Transactional Analysis Techniques, Self Esteem.

\section{Introduction}

Self-esteem is one of the important parts of a person's personality and is indispensable in the daily life of a human being. Based on (Coopersmith, 2011) Self-esteem is an assessment of a person's self in general and is related to how a person values himself, it describes an assessment to judge not on his own abilities and consider himself valuable, successful and important. In general, self-esteem is an important part of developing self-concept and representing oneself broadly, including behavioral and cognitive aspects that are affective and value-giving. (Santrok, 2003) reveals self-esteem is a dimension that evaluates to the self as a whole. Selfesteem is also known as self-image or self-esteem. Self-esteem is something that humans command to fulfill and then move on to a higher level of need. There are two types of self-esteem needed, namely appreciation 
from others and respect for yourself. An individual will need a pride and appreciation from others. Selfesteem is also obtained from the individual's success in overcoming life's challenges and therefore he will get pleasure. (Clemens \& Bean, 1995) stated that Self-esteem is from individuals in assessing themselves both negatively and positively. Self-esteem is related to the way an individual gives an assessment of himself and in the future will affect his behavior in life. There are many theories with the subject of Self-esteem, (Frey \& Carlock, 1984) argue that there are 2 important domains of Self-esteem, namely self-esteem and selfcompetence. Self-competence is what a person feels about self-esteem, with a feeling that he is able to live life.

Transactional analysis focuses on the behavioral, rational, and cognitive aspects of the individual. In addition, this analysis focuses on increasing awareness, so that a counselee is able to make the latest decisions and change the direction of his life. The integration of transactional analysis theory is carried out with various concepts, namely: the growth of children through injunctions and the giving of messages by their parents when making decisions.

According to the Transactional Analysis view, a person's present is the result of his childhood experiences and decisions that were determined long ago, but are still capable of change. Transactional analysis is based on the perception that the individual is able to understand his past decisions and decide again. The stages that need to be carried out in the implementation of group counseling. According to (Gladding, 2019) there are four steps, namely: (1) starting (Beggining a Group), (2) Substitution (The Tansition Stage in a Group), (3) working (The Working Stage in a Group); and (4) terminate (Termination of a Group).

\section{Method}

\section{Research Design}

The research model that the researcher uses is the 4-D development research model. The model was developed by (Thiagarajan et al., 1974). There are 4 important stages of the 4D development model, namely: Define, Design, Develop and Disseminate. The products developed in the research carried out are Group Counseling Guidebooks with Transactional Analysis Techniques to Improve Self Esteem of Vocational High School Students.

The subject under study is the Guidebook for Group Counseling with Transactional Analysis to Improve Self-Esteem of Vocational High School Students. While the test subjects for the acceptability test of this study were 3 judges or experts in the field of counseling and guidance and 2 practitioners. While the test subjects to test the effectiveness of the Transactional Analysis Counseling Guide to Improve Self-Esteem are students of class X SMK Negeri 2 Denpasar.

The expert will fill out a book validation sheet which is then used as proof of whether the Transactional Analysis Techniques Group Counseling Handbook is accepted or not. After filling is done, the results of the responses are analyzed using a CVR (Content Validity Ratio) based on theory (Lawshe, 1975). The following is the formula for calculating Content Validity Ratio (CVR):

$$
C V R=\frac{n e-\frac{N}{2}}{\frac{N}{2}}
$$

Information: (1) CVR : Content Validity Ratio, (2) $\mathrm{N}$ : total experts, (3) ne : total experts who give relevant values. The following are the criteria for making decisions based on the results of the CVR test: (1) if ne $<\mathrm{N}$ means CVR $<0$ (invalid), (2) if ne $<\mathrm{N}$ means CVR $=0$ (invalid), (3) if ne $>\mathrm{N}$ means CVR $<0$ (valid). 
After the CVR value is found, the overall validity value is determined through the Content Validity Index (CVI) (Lawshe, 1975). Here is the formula used:

$$
C V I=\frac{\sum C V R}{k}
$$

Description:

(1) CVI : content validity ratio,

(2) CVR : total content validity ratio,

(3) $\mathrm{k}$ : total items

Analysis of the data for the acceptance test of the guidebook with the criterion reference assessment can be seen from the level of mastery of the respondents, and it interprets the student's test scores in absolute terms. These results determine the students' ability to understand the skills and knowledge being tested. The following is the formula that researchers use in order to process values through LAP:

Rentangan $=$ Skor Riil__ $\times 100$

Skor maksimum ideal

Information: (1) Real score: the score that each respondent managed to achieve, (2) Maximum ideal score: the score with the possibility that the respondent is able to achieve if he gets a value of 4 when giving an answer, (3) 100: the use of a scale, namely a scale of 1 to 4

Testing the effectiveness of the Transactional analysis counseling guidebook to improve self-esteem was carried out through an independent sample-t test, which was to compare the self-esteem scores in the control group with the experimenter who took counseling. The following are the test criteria: (1) If Sig. (1-tailed) > 0.05 means that there is no difference in the average value of students' self-esteem after and before undergoing transactional analysis counseling techniques. (2) If Sig. (1-tailed) $<0.05$ means that there is a difference in the average value of self-esteem before and after undergoing counseling transactional analysis techniques.

To test the effectiveness of using transactional analysis techniques to improve students' self-esteem, an effective contribution was searched through the Cohen-D formula. here is the calculation:

\section{Effect Size $=$ pos test - pre tes Standard Deviation}

Table 01. Effect Size Interpretation Results

\begin{tabular}{rc}
\hline Nilai & Interpretasi \\
\hline $0-0.20$ & Weak \\
$0.21-0.50$ & Currently \\
$0.51-1.00$ & Enough \\
$>1.00$ & Strong \\
\hline
\end{tabular}

The following are the criteria for interpretation of effect size: (1) if the effect size is $<0.50$, it means that group counseling guides with transactional analysis techniques are less effective in terms of minimizing the level of self-esteem in students. (2) if the effect size $>0.50$ then the counseling guidance guides the group using transactional analysis techniques is in the effective category in order to minimize students' self-esteem. 


\section{Results and Discussion}

From these results, it shows that the Group Counseling Guidebook that the researcher developed has a good index regarding its validity, it is based on the assessments of the five practitioners and experts in the field of counseling guidance. Based on all the items in the instrument that the researcher uses, the group counseling guide book that the researcher developed has a good validity value on all of the items. Assessing content validity in counseling guidebooks is an important stage for developing counseling guidance services. The importance of the assessment to be carried out is intended so that before being used in serving students, the book is in accordance with theoretical acceptance.

Based on the results of the analysis of acceptability tests by experts and practitioners, using the Lawshe test, the CVR scores of each item exceeded $0(C V R>0)$ and no items were found to be below $0(C V R<0)$. Furthermore, the results of the Lawshe CVI analysis obtained a value of 1, which means that the acceptance of this manual is very high. So based on the value of the acquisition of effectiveness above, according to the criteria, showing an effect size value $>0.50$, the transactional analysis technique group counseling guide can be accepted.

\section{Conclusion}

The Transactional Analyst Handbook that is used to increase self-esteem is acceptable and needs to be developed for high school students and as a basis for Counseling Guidance teachers to find out the low level of self-esteem and deal with and alleviate student problems related to self-esteem.

From the research carried out, the results of the Lawshe CVR and CVI formula tests showed that the score of each item exceeded 0 (CVR $>0)$. Furthermore, the Lawshe CVI analysis obtained a value of 1 . From the data analysis carried out, it means that the value of the content validity of the guidebook product is of high value. Based on the data analysis, the group counseling guide book product is considered feasible to be developed.

Based on the results of the effectiveness test of the transactional analysis technique group counseling guide book, the value obtained is according to the criteria. If the effect size value is $>0.50$ then the transactional analysis group counseling guide can be accepted.

From the results of research and development, the following are suggestions from researchers: (1) This manual can be used by counseling guidance teachers to improve students' self-esteem and can provide more optimal school counseling services. (2) For researchers to be able to conduct a more in-depth study related to the effectiveness of this guidebook with a wider sample.

\section{References}

Clemens, \& Bean. (1995). Perbedaan Harga Diri (Self Esteem). Jurnal Psikologi UIN, 9(Desember), 100112.

Cohen, Manion, \& Morrison. (2007). Uji Keefektifan. Angewandte Chemie International Edition, 6(11), 951-952.

Coopersmith. (2011). harga diri (self esteem). La sociedad de la sociedad, 5-65.

Frey, \& Carlock. (1984). Frey dan Carlock (1984) dua komponen dalam Self esteem. pendidikan indonesia, $1967,8-26$.

Gladding. (2019). konseling analisis transaksional. urnal Bimbingan Konseling, 2015 - journal.unnes.ac.id.

Lawshe. (1975). Validitas Isi: Tahap Awal Pengembangan Kuesioner. Jurnal Riset Manajemen dan Bisnis (JRMB) Fakultas Ekonomi UNIAT, 2(2), 169-178. https://doi.org/10.36226/jrmb.v2i2.47

Santrok. (2003). Pelatihan Metode Self Instruction Untuk Meningkatkan Self Esteem Siswa SMA. Jurnal Pendidikan Dan Pengajaran, 1(47), 49-57.

Thiagarajan, S., D., \& Semmel, dan M. I. S. (1974: 5). (1974). pengembangan model 4-D. Model pengembangan 4-D (Four D). International Journal of Science, 89. https://eprints.uny.ac.id/30076/4 
The authors declare that they have no significant competing financial, professional or personal interests that might have influenced the performance or presentation of the work described in this manuscript.

First Publication Right: BISMA The Journal of Counseling

https://doi.org/10.xxxx/ xxxxx

Open Access Article | CC-BY Creative Commons Attribution 4.0 International License.

Word Count: 